Fırat Üniversitesi Sosyal Bilimler Dergisi

Firat University Journal of Social Science

Cilt: 26, Sayı: 1, Sayfa: 45-57, ELAZIĞ-2016

\title{
TÜRK EDEBİYATINDA BAHÂRİSTÂN*
}

Bahâristân Turkish Culture and Literature

\section{İbrahim Halil TUĞLUK** \\ ÖZET}

Mollâ Câmî'nin 1487 yılında telif ettiği Bahâristân; Mukaddime, sekiz bölüm ve Hâtime'den oluşan Farsça ahlâkî ve eğitici bir eserdir. Câmî, oğlu için kaleme aldığı Bahâristân'1 Hüseyin Baykara'ya ithaf etmiştir. Eserde, dünya hayatı için gerekli olan bilgi ve öğütler yer almaktadır. Câmî, Bahâristân'1 Sa'dî-i Şîrâzî'nin Gülistân'ını örnek alarak kaleme almıştır.

Osmanlı sahasında büyük ilgi gören Bahâristân medreselerde ders kitabı olarak okutulmuş, eserin çeviri ve şerhleri yapılmıştır. Çok sayıda yazması bulunan Bahâristân'ın özel lügatleri yapılmış ve aynı zamanda esere Nergisî tarafından Nihâlistân adında bir nazire de yazılmıştır.

Bu çalışmada Bahâristân'ın kütüphanelerimizde mevcut seçmeleri, şerhleri, lügatleri ile Bahâristân’a yazılan nazire ve eserin kültür tarihimizdeki yeri üzerinde durulacaktır.

Anahtar Kelimeler: Mollâ Câmî, Bahâristân, seçmeler, şerh, çevri, lügat, nazire, kültür tarihi.

\section{ABSTRACT}

Bahâristân that Mollâ Câmî wrote in 1487 is a moral and educational work in Persian and consists of introduction, eight section and epilog. Câmî dedicated Bahâristân that he wrote for his son to Hüseyin Baykara. Advices and information necessary for world life exist in this work. Câmî wrote Bahâristân respect to sample of Sa'dî-i Şîrâzî's Gülistân.

Bahâristân that takes a great interest in Ottoman field has been read in medresas as lecture book, translations and explanations of the work has been done. Special wordbooks of Bahâristân that has a lot of manuscript have been done and a nazira called Nihâlistan has been written by Nergisî also.

In this study, it will be emphaised on the available selections, explanations, wordbooks and naziras of Bahâristân in our libraries and its position in our cultural history.

Key Words: Mollâ Câmî, Bahâristân, selections, explanations, wordbook, nazira.

\section{GíRIŞ}

Türk-İran münasebetleri; dinî, siyasî, coğrafî, ekonomik vb. etkenlerle şekillenen, kültürel ve edebî uzun bir geçmişe sahiptir. İran'da hüküm süren hanedanların çoğunun Türk olması, Fars edebiyatının önemli şahsiyetlerinin (Ferrûh-1 Sistânî, Menûçihrî, Mu'izzî, Hâkânî, Emîr Hüsrev, Sâ'ib-i Tebrîzî, Nizâmî vb.) Türk kökenli olması Fars edebiyatında Türk kültürünün izlerini bırakmış, bu izler Fars klasik edebiyatının şekillenmesinde etkili olmuştur. Bunun yanı sıra Anadolu sahasında Farsça eser kaleme alan birçok şair de vardır. ${ }^{1} \mathrm{Bu}$ karşılıklı ilişkinin etkisi, kapsamı, doğrudan veya dolaylı tesirleri, sınırları incelenmeye muhtaç olmakla birlikte Fars sahasında bir Türk edebiyatı, Anadolu sahasında da Türkçenin ifade biçimine bürünmüş bir Fars edebiyatını netice vermiştir. Türk-Fars dairesi edebî ilişkileri bu çerçeveyle sınırlı kalmamış, Farsçadan Türkçeye, Türkçeden Farsçaya manzum veya mensur eserler tercüme edilmiştir. Ferîdüddîn Attâr, Hâfiz-1 Şîrâzî, Sa'dî-i Şîrâzî, Mollâ Câmî ve daha birçok şahsiyete ait eserlerinin tercümeleri yapılmış, tercüme edilen eserler bazen te’life varacak kadar yeniden yorumlanmış,

\footnotetext{
* Bu çalışma 15-17 Mayıs 2012 ‘de İstanbul’da düzenlenen I. Uluslararası Türk-İ́ran Dil ve Edebiyat İlişkileri Sempozyumu'nda sunulan “Türk Kültür ve Edebiyatı'nda Bahâristân” adlı bildirinin gözden geçirilmiş ve genişletilmiş şeklidir.

${ }^{* *}$ Doç. Dr., Adıyaman Üniversitesi, Fen Edebiyat Fakültesi, Türk Dili ve Edebiyatı Bölümü, itugluk@adiyaman.edu.tr

${ }^{1}$ Anadolu sahasında Farsça şiir kaleme alan şairler için bkz. Riyahi, Muhammed Emin, Osmanlı Topraklarında Fars Dili ve Edebiyatı, çev. Mehmet Kanar, İstanbul 1995.
} 


\section{F.Ü. Sosyal Bilimler Dergisi 2016-26/1}

eserin tümünün ya da bir bölümünün-dibâce şerhleri- yapılmış, bu eserlerin seçmeleri hazırlanmış, aynı zamanda eserlerin lügatleri de yapılmıştır. ${ }^{2}$

$\mathrm{Bu}$ çalışmada, Anadolu sahası üzerinde önemli etkileri görülen 15. yüzyılın önemli simalarından Mollâ Câmî'nin Bahâristân adlı eserinin Türk kültür ve edebiyatındaki yansımaları üzerinde durulacaktır.

\section{Mollâ Câmî’nin Hayatı ve Eserleri}

İran'ın ve bütün İslam dünyasının tanınmış şahsiyetlerinden Mollâ Câmî, Câm kasabasının Hurdcird köyünde 23 Şaban 817/1414-1415'te doğmuştur. Babası Ahmet bin Muhammedü'dDeştî'dir. Câmî, küçük yaşlarından itibaren önce babasından, sonra da dönemin önemli hocalarından ders almış, Nakşibendiye tarikatından Kaşgarlı Şeyh Sâdettin'e intisap etmiştir. Hüseyin Baykara ve Ali Şîr Nevâî’nin himayelerini görmüş olan Mollâ Câmî, her biri İslam dünyasında olduğu gibi Türk sahasında da etkili olan birçok eser kaleme almıştır. Câmî, 898/14921493'te 81 yaşında vefat etmiştir (Hikmet, 1996: 101-126; Macit, 1991: 519).

Anadolu sahası şairlerinden bazılarıyla birlikte eğitim de almış olan Mollâ Câmî, Nakşibendi tarikatının Anadolu'da dolaylı olarak yayılması, eserleri, ilmî kişiliği ve Herat ekolü vasıtasıyla Osmanlı sahası üzerinde etkili olmuştur. (Macit, 1991: 520-522)

\section{Bahâristân}

Bahâristân, Câmî'nin kaleme aldığı önemli eserlerdendir. Ahlâkî ve edebî bir eser olan Bahâristân'1 Câmî, oğlu Ziyâeddin Yusuf'un Arap dili ve edebiyatını öğrenmeğe başladığ1 dönemde kaleme almıştır. Câmî, bunu Bahâristân'da şu şekilde dile getirmiştir: “....şimdi bu Bahâristân'ın yazılmasındaki sebebi anlatmak sırası gelmiștir. Bu gönül okșayıcı bahar çağlarında sevgili oğlum Ziyâeddin Yusuf (Allah kederlerden saklasin) Arap dilini ve edebiyat bilgilerini öğrenmeğe çalışıyordu. Yeni yetişmekte olan çocuklara ve zahmet görmemiş olan yavrulara, alışkın olmadıkları şeylerle zihinlerine uygun gelmeyen yabancı terimleri öğretmenin, onlara ağır bir yük olmakla beraber gönüllerine korku vereceği pek açık bir hakikattir. Çocuğun gönlünü ferahlandırmak ve hatırını hoş tutmak için ara sıra ünlü şeyh ve büyük üstat Şîrâzlı Muslihuddin Sa'dî'nin mübarek nefeslerinden olan Gülistân kitabından birkaç satır okurduk. ... O sırada hatırıma geldi ki Sa'dî'nin mutlu nefeslerine, güzel şiirlerine benzer birkaç yaprak da teberrüken aynı üslûp üzere ben yazayım. İște hâlihazırda bir destân ve gaiplere bir armağan olmak için şu birkaç parça bu suretle tertip edildi. Bu yazılar sona erince bu eser de tamamlandı." (Gençosman, 1990: 4-5)

Câmî'nin 892/1478'de Sa'dî'nin Gülistân adlı eserini örnek alarak yazdığı ve Sultan Hüseyin Baykara'ya ithaf ettiği Bahâristân tertip ve üslûp bakımından Gülistân'a benzese de muhteva açısından Gülistân'dan farklılıklar gösterir. Ravzatü'l-ahyâr ve Tuhfetü'1-ebrâr adılyla da anılan Bahâristân, yine Gülistân gibi nesir-nazım karışık bir eserdir. Eser bir mukaddime, sekiz bölüm (ravza) ve bir hatimeden meydana gelir. Her bölümün başında konu tarif edildikten sonra bölümün özelliğine göre bu konular "hikâyet", "hikmet" veya "mutâyebe" alt başlıkları şeklinde işlenir. (Okumuş, 1991: 470-471) Bahâristân şu bölümlerden oluşur:

1. Büyük sofilerden bazılarına ait hikâyeler,

2. Filozoflardan derlenmiş sözler,

3. Sultanlarda adalet,

4. Cömertlik ve kerem,

5. Așk ahvâli,

6. Aşk ve latifeler,

7. Şairlerin ahvâli

8. Hayvanlar dilinden nakledilen hikâye ve fikralar.

\footnotetext{
${ }^{2}$ Bu konuda geniş bilgi için bkz. Ahmet Kartal, “Türk-Fars Edebi İlişkileri”, Şiraz’dan İstanbul'a Türk-Fars Kültür Coğrafyası Üzerine Araştırmalar, Kurtuba Kitap, İstanbul, 2010, s. 13-117.
} 


\section{Türk Edebiyatında Bahâristân}

Bahâristân, Doğu kültürünün klâsikleri arasında yerini almış bir eserdir. Doğu ve Batı dillerinde birçok çalışmaya konu olan Bahâristân ile ilgili Osmanlı döneminde ve Cumhuriyet döneminde eserler kaleme alınmıştır. Bu çalışmalar; eserin tamamının veya bir kısmının asıl metne sadık kalınarak veya adapte edilerek tercümesi, eserin tamamının ya da bir kısmının, özellikle dibâce bölümünün şerhi, eserin tamamı ya da bir kısmının lügatlarının hazırlanması ve müntehabatları (seçmeler) vb. şeklindedir.

Bahâristân, Divan şiirinde Gülistân, Bostân, Mantıku’t-tayr vb. eserlerde olduğu gibi bir metafor olarak da kullanılmıştır.

\section{A. Osmanlı ve Cumhuriyet Döneminde Yapılan Bahâristân Tercümeleri}

\section{Osmanlı Döneminde Yapılan Tercümeler}

Bahâristân'ın Osmanlı döneminde tespit edilen üç tercümesi vardır:

\section{a. Tuhfe-i Âsitân Tercüme-i Bahâristân ${ }^{3}$}

Alî el-Mevlevî tarafından kaleme alınan tercümenin Türkiye kütüphanelerinde iki nüshası vardir:

1. Derviş Muhammed Alî el-Mevlevi, Tercüme-i Bahâristân, Müst. Ömer el-Buhârî, Süleymaniye, Nafiz Paşa, 849, 107 vr.

2. Derviş Muhammed Alî El-Mevlevi, Tuhfe-i Âsitân Tercüme-i Bahâristân, Dil Tarih Coğrafya Fakültesi, Mustafa Con A, 401/XI.

Alî el-Mevlevî, tercümeyi şeyhi Ebubekir Efendi'nin isteği üzerine kaleme almıştır. Ebubekir Efendi, Alî el-Mevlevî'den Bahâristân'1 Türkçeye tercüme etmesi durumunda faydasının genel olacağını belirtmiştir. Derviş Muhammed Alî el-Mevlevî, eseri kaleme alışını şu şekilde anlatır: "ammâ ba'd ma'lûm-1 e'izze-i ihvân ve nümûde-i ecille-i hullân olsun ki bu kitâb-1 müstetâbın tercemesine sebeb oldur ki bu 'abd-i nâ-tüvân ve hâk-pây-1 fukarâ-yı Mevleviyân a'nî Derviș Muhammed 'Alî el-Mevlevî gafere'llâhu zünûbehu ve setere'uyûbehû nice zamân vâdi-i hasretde pûyân ve be-vâdi-i dacretde devân u pây-kûbân olup âhir-i kâr Hazret-i Pîr-i dest-gîrim Mevlânâ ve mevle'l- 'ârifin kaddasa'llâhu bi-sirrihi'l-mübîn dergâhına hezâr iştiyâkla rûy-1 siyâhım sûde ve bir gûş̧e-i kerâmet-tûş̧ede karâr-dâde olduğumuz âvânede ol pị̂̂âa-yı erbâb-1 tarîkat ve cedd-i bozorgvâr-1 hakîkat Şeyhim Sultânım veliyyü'n-ni`em ve 'aliyyü'l-himem zümre-i meşâyihin ser-bülendi a'nî bihi el-Hâc Es's-seyyid Ebû Bekir Efendi medde'llâhu zilâle re'fetihi alâ mefâriki'l-fukarâi'ssâlikîn hazretlerinin vâlid-i mâcidleri e's-Seyyid Muhammed 'Ârif Efendi tayyebe'llâhu serâhu ve ce'ala mak'ada sıdkihi me'vâhu hazretleri bin yüz elli tokuz târihi saferü'l-hayrın yigirmi birinci günü vedâ'-1 'âlem-i fầni buyurup ravdatu'l-ervâhi't-tayyîbe olan türbe-i mukaddese-i cedd-i emcedlerine âsûde-i civâr-1 rahmet-i Rahmân olduklarında kendiler bi'l-fi'l mesned-ârâ-yı hilâfet-i peder-i bozorg-vârî ve müttekâ-zîb-i meşîhat-1 türbe-i hudâvendigârî olup bu bende-i ahkarlarına nazar-1 'inâyet buyurup tarîkatı hıdmetine istihdâm ve sohbet-i pür-bereketleriyle vakt-â-vakt muğtanem olduğumuz esnâda el-kelâm yecürrü'l-kelâm ${ }^{4}$ mağzâsınca yevmen mine'l-eyyâm silsile-i sohbet-i 'ilmiyyeleri Hazret-i Câmî'nin Bahâristân ismiyle müsemmâ olan te 'lîf-i letâyif-elîflerine müncer oldukda âyâ ol nüsha-i latîfede olan elfầz $u$ 'ibârât-1 Fârisiyye lisân-1 Türkîye tercüme kılınsa nef'i 'âm ve şîve-i uhrâyla dahi tâm olurdı buyurduklarında

Misra':

Der-tarîkat her çi pîş-i sâlik âyed hayr-1 ost $t^{5}$

\footnotetext{
${ }^{3} \mathrm{Bu}$ eser, proje kapsamında tarafımızca çalışılmaktadır.

4 "Söz sözü açar." anlamında bir Arap sözü.

5 "Tarikatta sâlikin önüne ne gelirse o hayırdır."
} 


\section{F.Ü. Sosyal Bilimler Dergisi 2016-26/1}

mazmûnınca bu fakîr-i pür-kusûr hezâr 'acz ü fütûr ile mevsûf iken nefes-i cân-bahşlarına mu'temeden zebân-âverlik idüp

Misra':

Ger mecâl-i goft bûdî goftenîhâ goftemî

Eger himmet-i bî-hemtânız bu 'abd-i 'âcizi intâka masrûf kılunur ise bu emr-i hatîr bimeşiyyeti'llâhi Te' âlâ husûl-pezîr olur. El-me'mûru ma'zûrun ${ }^{7}$ diyüp emr-i lâzimü'l-ittibâ'ları muktazâsinca ma'a kıllati'l-bidâ'a ve 'illet-i 'ademü'l-istitâ'a tevekkülen 'alâ'llâhi te'âlâ ve teşebbüsen bi-zeyl-i himmet-i Mevlânâ silk-i takrîr ve rişte-i tahrîre bu cevâhir-i zevâhiri tasmît k1lup Tuhfe-i Âsitân Tercüme-i Bahâristân demekle tesmiye olundı. Hattâ hâzırân-1 dostâna dâstân1 'ibret-beyân ve ğâa'ibân-1 ihvâna yâdgâr $u$ armağan olup behre-mend-i ikrâmât ed'iyye-i hayriyyeleri kılalar bi-mennihi ve keremihi subhânehu ve Te'âlâ Allâhümme es'elüke'l-ismete 'an zeleli'i-halel. Imdi işbu kitâb-1 ra'nâ bihiştâsâ heșt ravza olmak üzere tertîb ü tedvîn ve her ravzası şükûfe-zâr-1 nikât-1 Bahâristân ve terâvet-fersâ-yı hezâr Gülistân olmak üzre tezyîn k1lınmışdır." (Süleymaniye Nafiz Paşa, 2a-3a)

\section{b. Filibe Müderrisi Hızır-zâde Mehmed Fevzî, Bahâristân Tercümesi ${ }^{8}$}

Mehmed Fevzî Efendi tarafından tercüme edilen eser, 1227/1812-1813'te Şirket-i Sahâfiye-i Osmâniyye Matbaası'nda basılmıştır. 88 sayfadan oluşan esere Mehmet Fevzî Efendi, doğrudan tercüme ile başlamıştır.

c. Hakkî, Mecmua, Bahâristân Çevirisi, Topkapı Sarayı Müzesi Kütüphanesi, Hazine, 1711.

III. Mehmed dönemi Saray Babüssaade Ağası Gazanfer Ağa'nın ricası ve himayesiyle çevrilen eser, 1b-37b varakları arasındadır. Nesihle yazılmıştır. Sekiz bölümde hayvanlarla ilgili hikayeler vardır. Eser, on dört minyatürle süslenmiştir. Eser bu açıdan da değerlidir. (Çağman, 1978)

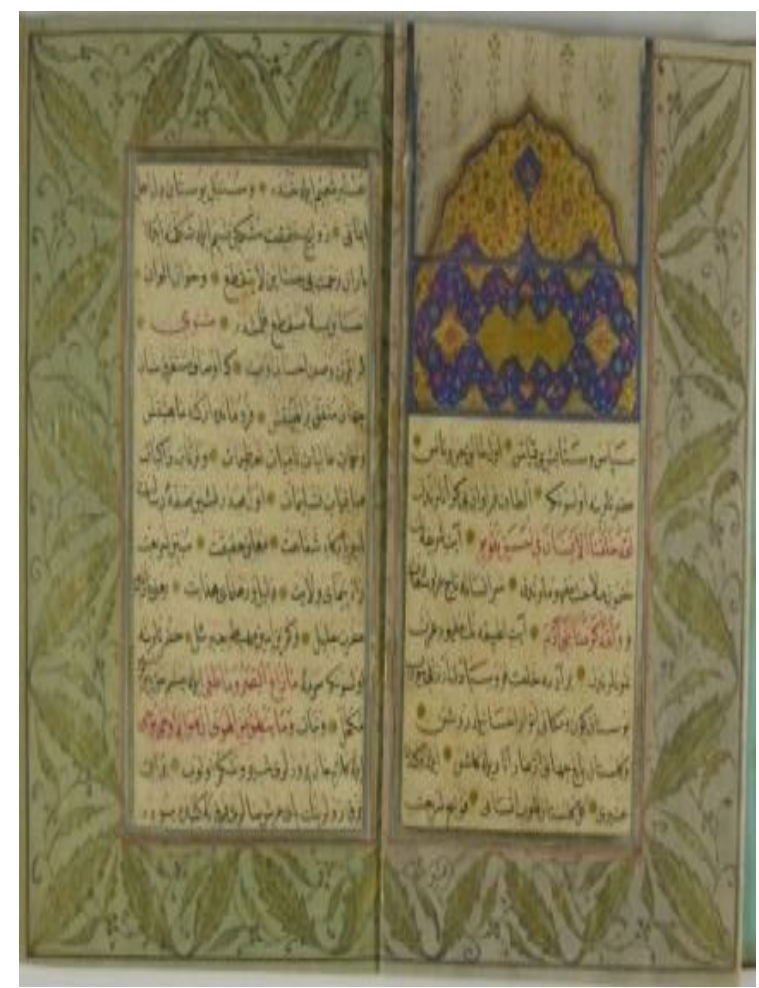

(Topkap1 Hazine 1711, 1b-2a)

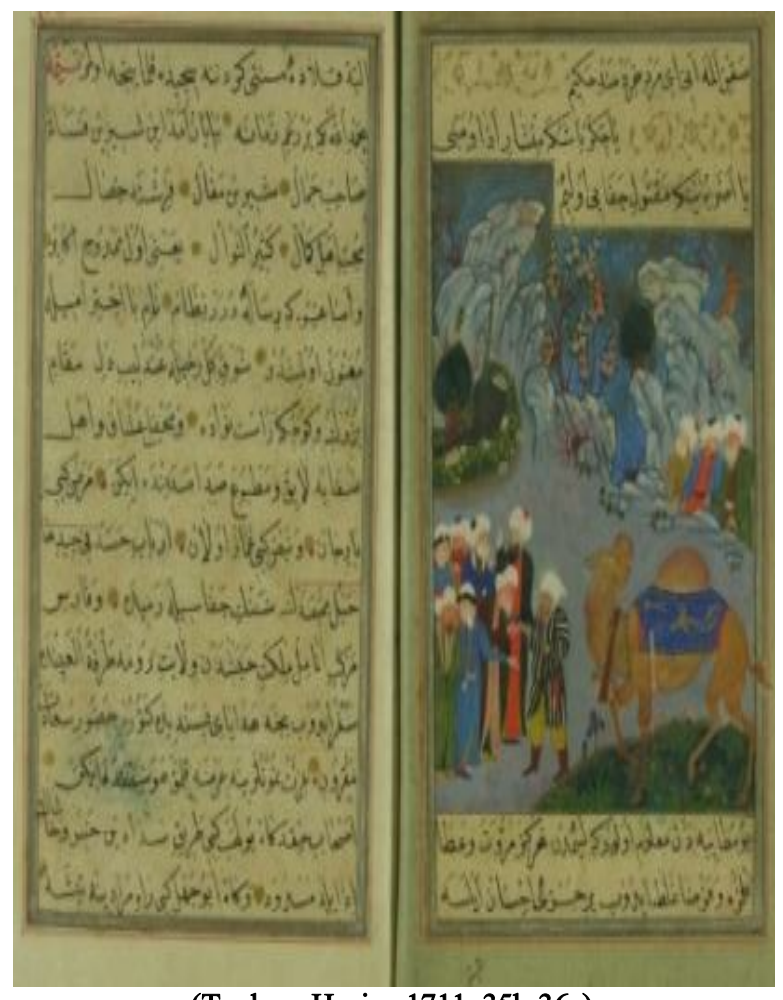

(Topkapı Hazine 1711, 35b-36a)

\footnotetext{
6 "Söyleme imkânı olsaydı ne sözler söylerdim.”

7 "Emrolunan ma'zûrdur."

${ }^{8} \mathrm{Bu}$ eser, proje kapsamında tarafımızca çalışılmaktadır.
} 


\section{d. Tercüme-i Hikâyâtü'l-Meşâyih-i Kitâb-1 Bahâristân min Te'lîf-i Mevlânâ Câmî9}

Rıfat Mehmet Kâdirî (ö. 10 Ramazan 1317 / 10 Ocak 1900) tarafindan yapılan tercümenin iki nüshası vardır:

1. İstanbul Büyükşehir Belediyesi, Atatürk Kitaplığı, O.E. 740, 67b-120a.

2. İstanbul Büyükşehir Belediyesi, Atatürk Kitaplığı, O. E. 1826, 1b-11a.

Eser, Mehmet Rıfat'ın Bahâristân'ın tercüme sebeplerini anlattığı dokuz beyitlik bir mesnevi ile başlar. Bahâristân'ın Mollâ Câmî tarafından kaleme alındığını belirten yazar, Bahâristân'da birçok latife bulunduğunu belirtir. Tasavvuf ehlinin istifade etmesi için birçok hikâye içeren eserden herkesin faydalanması amaciyla eseri Farsçadan Türkçeye tercüme ettiğin ifade eder.
Çün Bahāristān derler bir kitāb
Vardır anda hem letayif bì-hesāb
Mollâ Câmî anı te'lîf eylemiş
İsm-i ehlu'llāhı ta' rîf eylemiş
Yazilıp her bir hikâye bend bend
Olmak için sālikānı hisse-mend
Nakl olundu Fârisîden Türkîye
Okuyup her adam etsin fă'ide
Dedi bu Rif'at Muhammed Kâdirî

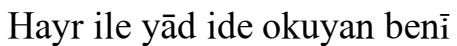

\section{Cumhuriyet Döneminde Yapılan Tercümeler}

Cumhuriyet döneminde Bahâristân'ın beş tercümesi yapılmıştır. Kronolojik sıralamaya göre bu tercümeler şunlardır:

\section{a. Kilisli Rıfat Bilge, Bahâristân, Meral Yayınevi, İstanbul, 1945.}

Mütercim, eserini tercüme etmeye muvaffak olmuş ancak neşrine fursat bulamamıştır. Mukaddime ve Bahâristân tercümesinden oluşan eser, 144 sayfadır. Önsöz'de Câmî'nin biyografisi, Bahâristân hakkında malumat ve Kilisli Rıfat Bey hakkında bilgi verilmiştir. Tercümede herhangi bir dipnot yoktur.

\section{b. M. Nuri Gençosman, Bahâristân, Ankara Üniversitesi Basımevi Ankara, 1963.}

$\mathrm{Bu}$ tercüme bir Önsöz ve Bahâristân tercümesinden oluşmaktadır. Önsöz'de Gençosman, Câmî'nin kısaca hayatı, şöhreti, 15. yüzyıl İran'ın siyası çehresi, İkinci Bayezid ile mektuplaşmaları, Hüseyin Baykara ile münasebeti, Bahâristân'la Gülistan mukayesesi, Câmî'nin biyografisinin kaynakları, Batılı araştırmacıların Câmî hakkındaki değerlendirmeleri, Câmî'nin tasavvufi yönü, eserleri, Türkiye'de tanınmış eserleri, ölümü ve mezarının yerinin değiştirilmesi üzerinde durmaktadır. Gençosman, dipnotlarda özel isimler ve kavramlarla ilgili açıklamalarda bulunmuş, yer yer nükteler aktarmıştır.

c. Yakup Kenan Necefzâde, Bahâristan, Neşriyat Yurdu, Yeni Şark Maarif Kütüphanesi, İstanbul, 1967.

Eser; Önsöz ile Câmî'nin biyografisi, Mevlânâ hakkındaki bir beyti, seyahatleri, eserleri ve Bahâristân tercümesinden oluşmaktadır. Tercümede kavram açılamaları içeren birkaç dipnot vardir.

\footnotetext{
${ }^{9} \mathrm{Bu}$ eser, proje kapsamında tarafımızca çalışılmaktadır.
} 


\section{F.Ü. Sosyal Bilimler Dergisi 2016-26/1}

\section{d. Sadık Yalsızuçanlar, Baharistan, Akçağ Yayınları, Ankara, 2001.}

Bahâristân, Sadık Yalsızuçanlar tarafından daha çok edebî bir üslupla tercüme edilmiştir.

\section{e. Adnan Karaismailoğlu, Baharistan, Akçağ Yayınlan, Ankara, 2002.}

Eser, bir Önsöz ve asıl eserin tercümesinden oluşmaktadır. Önsöz'de yazar, Câmî'nin kısaca hayatı, Fatih Sultan Mehmet ve II. Bayezid ile mektuplaşmaları, eserleri, Bahâristân'ın telif tarihi, sebeb-i telifi, kime sunulduğu, bölümleri, Türkçe şerh ve çevirileri, tercümeye esas alınan metin ve Bahâristan'ın muhtevası, tercümenin tekniği hakkında bilgiler vermiştir. Mütercim, Mehmet Şâkir'in Şerh-i Bahâristân'ından da istifade ettiğini belirtmiştir. Dipnotlarda özel şahıslar, yer isimleri ve kavramlarla ilgili bilgiler verilmiştir.

\section{Müntehâbâtlar (Seçmeler)}

Bahâristân'dan yapılan seçmeleri içeren eserlerdir. Bunlardan tespit ettiğimiz ancak ulaşamadığımız altı tanesi Gazi Hüsrev Bey Kütüphanesi Türkçe Yazmaları bölümündedir. Milli Kütüphane'de bulunan bir mecmuada da 11 farklı varakta Bahâristân'dan seçme hikâyeler ve şiirler vardır.

1. Müntehâb-1 Bahâristân, Gazi Hüsrev Kütüphanesi Türkçe Yazmaları, 5103, 1140 (1728), 24 vr.

2. Müntehâb-1 Bahâristân, Gazi Hüsrev Kütüphanesi Türkçe Yazmaları, 2510, 74 vr.

3. Müntehâb-1 Bahâristân, Gazi Hüsrev Kütüphanesi Türkçe Yazmaları, 1455, 55 vr.,

4. Müntehab-1 Bahâristân, Gazi Hüsrev Kütüphanesi Türkçe Yazmaları, 1597,

5. Müntehâb-1 Bahâristân, Gazi Hüsrev Kütüphanesi Türkçe Yazmaları, 1812, 111 vr.

6. Müntehâb-1 Bahâristân, Gazi Hüsrev Kütüphanesi Türkçe Yazmaları, 2768/1, 1-74a.

7. Mecmûa-i Eş'âr, Milli Kütüphane, 06 Mil Yz A 28112.

\section{4. Şerhler}

\section{a. Dîbâce Şerhi}

1. Himmet-zâde Abdî Efendî, (öl. 1122/1710), Şerh-i Müşkilât-1 Dîbâce-i Bahâristân, Süleymaniye Âşir Efendi Koleksiyonu, 435/13, vr. 137b-143a; Şerh-i Dîbâce-i Bahâristân, Süleymaniye Kasidecizade, 724-14, 140-147 y.

Himmet-zâde Abdî Efendi, eserine hamd ve salvele ile başlamıştır. Abdî, eserini Dibâcede anlaşılması zor manzum ve mensur parçaların anlaşılmasını kolaylaştırmak için yazdığını belirtir. Abdî, eseri kaleme alışını şu şekilde anlatır: "ve ecda'-1 mahmûdu'ş-şu'arâ ve mevdûdu'l-büleğâ Şeyh Câmî revvahahu'llâhu'l-hâmî Fezâ'il-i Bahâristan'inda Resâil-i Gülistân-1 resûlden bu kavl iktibâs ve șefâ'at-1 Resûl iltimâs kılup sâhib-i seb'a'l-mesânînün ma'âni-i 'acâyibden kitâb-1 evvelinde mektûb olmağı savâb gördü. Pes Dîbâcesi'nde ba'zı müşkilat-1 ebyât ve mufassılât-1 inşâ'iyyât vâki' olup mübtedîlerinün zihnine 'asîr ve muktedîlerün fehmlerinden nefîr olduğu eclden bu za'îf-i pejmürde-dil ve nahif-i bârende-i seyl 'adem-i ihtiyâc-1 ihvânı bilürken 'alâ kadri't-tâka istihrâc olan 'alâ vechi'l-meşrûh ve'l-mevzû' beyân u 'ayân kıldı." (Süleymaniye Kasideci-zâde, 122a, Süleymaniye Aşir Ef. 1b-2a) ${ }^{10}$

\section{b. Bahâristân'ın Tümünü Şerh Eden Eserler}

Bahâristân'ın bilinen Türkçe iki şerhi vardır:

\section{1. Şem'î, Şerh-i Bahâristân}

Yurt içi ve yurt dışı kütüphanelerinde birçok nüshası vardır. (Akat, 1999)

\footnotetext{
${ }^{10}$ Lâmi'î Çelebi’ye ait ve Topkapı Sarayı Revan 1884 numaraya Şerh-i Dibâce-i Bahâristân adıyla kayıtlı eser, Sa'dî̀-i Şîrâzî’nin Gülistân adlı eserinin Dîbâce şerhidir.
} 


\section{Mehmed Şâkir, Hediyyetü'l-İrfân der-Şerh-i Bahâristân ${ }^{11}$}

Mehmed Şâkir Efendi tarafından kaleme alınan ${ }^{12}$ ve 607 sayfadan oluşan eser, İstanbul'da 1252/136-37'de Matbaa-i Âmire'de basılmıştır. Eserine tahmîd, salvele ve dört halifeye övgü ile başlayan Mehmed Şâkir, eserinin şerhe layık olmadığını ifade etse de Şem’̂̀’nin şerhinin Bahâristân'ın anlamlarını gereği gibi izah edemediğini belirtmiştir: “... reng-i elvân-1 ma'ânîsi çerâğân-1 tercüme ile rûşenâ olmadığı ma'lûm-ı bîgâne vü âşinâdır. Her ne kadar Şem'î merhûm ol vâdîde tek u pû etdiyse de șebistân-1 hayâlâtını gereği gibi rûșen edemediği kitabılyla müberhendir. Bu lâlezâr-1 ma'ânîde şiddet-i nesâyîm sebebiyle şem'-i beyânı fürûzân olmayıp kemâ hüve bâkî kalmıştır." (Mehmed Şâkir, 3).

Şâkir Efendi, eserinde metnin zorluklarını, Farsça kuralları, nazım bölümlerinin anlamlarını izah etmiştir. Sultan Selim methinde bir kaside kaleme alan şârih, eserinin ismini Hediyyetü'-İrfân der Şerh-i Bahâristân koymuştur. Şâkir Efendi, kelime ve ibarelerin gramatikal tahlilini yapmış, sonra da "mahsûl-1 beyt" başlığı altında ibarenin anlam boyutu üzerinde durmuştur. "Arûz" başlı̆̆1 altında nazım parçalarının veznini incelemiştir. Yeri geldiğinde "Mahsûl" başlığı altında terkib, ibare gibi parçalara yorumlar getirmiştir. Yer yer nüsha farklllıklarına da değinmiştir. Şerhini bir mesnevi ile bitiren Mehmed Şâkir, 606. sayfada Mevlânâ Câmî’nin hayatını anlatır.

\section{Lügat}

a.Lügat-1 Bahâristân, Türk Dil Kurumu Kütüphanesi, Yz. A 210/16, 237b-261b. ${ }^{13}$

b. Lügat-1 Bahâristân, DTCF Ktp. İ. Saib II, 1438, 38b-56b. (Arslan, 2013, 596)

Müellifi ve telif tarihi bilinmeyen ve alfabetik olarak tertip edilen eserde alfabetik olarak Arapça Farsça kelimelerin Türkçe anlamları verilmiştir. Her bir harf "Fasıl" başlığı altında verilmiştir (234a-243a). Sonra müfred masdarların, çoğul masdarların, olumlu-olumsuz biçimleri; geçmiş zaman, gelecek zaman, emir çekimleri, ism-i fâ'il, ism-i mef' ûl biçimleri verilmiştir. I'lem başlığı altında Arapça olarak Farsça kelimelerin türetimiyle ilgili bilgiler verilmiştir. Dolayısıyla sözlük aynı zamanda Farsçayı öğretmeyi hedefleyen bir lügattir. Eserin tespit edilebilen tek nüshası vardir.

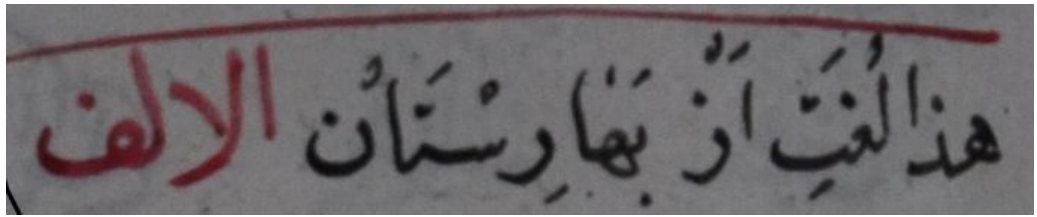

(Hâzâ Lugat-i ez-Bahâristân El elif)

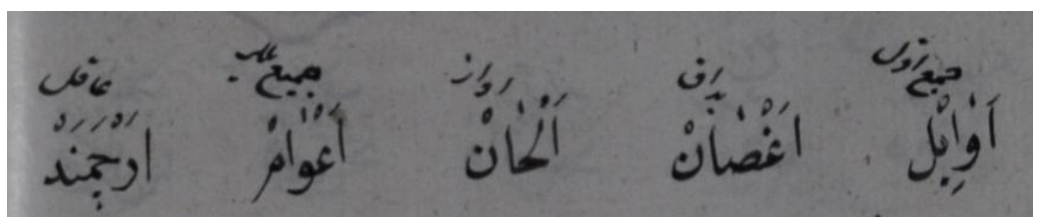

\footnotetext{
${ }^{11} \mathrm{Bu}$ eser, proje kapsamında tarafımızca çalışılmaktadır.

${ }^{12}$ Bağçe-i Safâ-endûz' da Mehmed Şâkir'in hayatının anlatıldığı bölümde Şâkir Efendi'nin (Çukadâr Ahmed Agazâde'nin) Bahâristân'ı şerh ettiği şu şekilde anlatılmıştır: "Ístanbul'da Eski Otalar [Hâlen Fevziye tesmiye olunan mahaldir] kurbunda 'Üryânî Dedenin türbesi olan hânede sâkin sadr-1 a'zam çukadârlanından Ahmed Aga-nâm zâtın oglıdur. Dört yaşında mâderinden Şâhidî ve Subha-i Sibyân manzûmelerini okuyup ve kable'l-bülûg sarf u nahvi dahi görüp Sultân Ahmed Hân-1 Sâlis silehdârlarından Hançerli İbrâhîm Aga'ya karâbeti olmagla hazîne-i hümâyûna almışlar orada Şevkî Ahmed Efendi'den ve Yûsuf Efendi'den nesh okumuş ve Bahâristân-1 Câmî kuddise sırrahûyı sarâyda iken Sürûrî-âsâ muhakkikâne şerh eyledigini sâhib-tezkire yazar ve fi'l-hakîka Münîbâsâ fuzalânın karîn-i takrîzleri olmış güzel eserdir. (Oğraş, 2001: 135)

${ }^{13}$ Arapça-Farsça-Türkçe, nesih hatla, 215x155-160x95 mm. ölçüsünde, 9 satırl1, 237b-261b. Noktalar, çizgiler ve konu başları kırmızıdır. Sırtı ve sertâbı kahverengi meşin, kapaklar mavi, müzehhep, dört köşe, kahverengi meşin, zencirekli, mıklebli, içi ebru kaplı bir cilt içerisindedir. Sözcüklerin Türkçe karşılıkları satır aralarındadır.
} 


\section{Nazîre}

Nergisî, Gülistân ve Baharistân'a bir nazire olması için eserine Nihâlistân adını verir. (Çaldak, 2010: 156) "Okuma ve yazmaya başladığı günden beri hocaların mübtedi öğrencilere ilk olarak Gülistân ve Bahâristân gibi kitapları okutmaları dikkatini çeker. Aslında pek çok değerli ögüdü, hikmetli hikâye ve sözü ihtiva eden bu eserler, sadece bu işe başlayan gençler için değil, ihtiyarlar için de yaşl1lık dönemlerinin tek teselli kaynağı olagelmiştir. Gerçekten de Fars ülkesinin güçlü kalemleri, bu eserleriyle zamanın eline her an bahar havası yaşatan birer armağan vererek, kendilerinin asırlar boyunca güzel bir nâm ile anılmalarını sağlamışlardır. Anadoluda yetişen kalem erbabından birinin de inşâ sahasında yeni bir tarz ve üslûp ile yazılmış bir eseri asra armağan ve zamanın sanatperver-lerine hediye etmesini yazar, uzun bir zaman hasretle beklemiş̧ir. Halbuki "lisān-1 hoş-beyān-1 Türkī ”, çeşitli dillerden derlediği güzel kelime çiçekleriyle müstesna ve onlardan devşirdiği meyveler ile zevk-i selim sahiplerince beğenilen bir dildir. Türkçe bu derece "hüsn-i edā"ya müsait ve münasip olduğu halde Osmanlı ülkesinin söz ustalarının, "bì-iktidārī " töhmeti ile utanarak acz ve zaafiyet ile yüzlerinin "şikeste-reng-i inkisār" olması revâ değildir. Bu ateşle yüreğinin yanıp tutuştuğunu söyleyen yazar, görevinden dolayı daima göçüp konmak zorunda kalır. (Çaldak, 2010: 159-160) "...dil-pezīr-i pesendīde imlā ve ihtilāf-1 meşārib-i 'ālemiyāna binā'en her kese hāhiş-i dāniş-āmūz-1 isti' dādı üzre șūret-nümāy-1 ma'nā olacak bir tuhfe-i nev-peydā olması enseb ü evlā görilmekle kef-dest-i sem` ile dehen-i rāviyān-1 șahīhu'lkelāmdan rübūde-i 'ayyār-1 fehm-i tīz-dest olan ğarā'ib-i āsār-1 hayret-efzāa șahn-1 būstān-1 $m u^{`}$ àyeneden çīde-i yemīn-i nazar-1 dürüst-bīn olan kazāyā-yı ta'accüb-fermāya zamm u ilhāk olınup vaktā ki manzūr u mesmū' bir nice ahbār-1 sahīhu'l-vukū' bu vechile sūret-yāb-1 iltișāk oldı reşha-i ārzū-yı sābıḳu'l-beyān ya'nī lisān-1 Türkīde nažìre-i Gülistān ü Bahāristān ibdā' 1 nāvdān-1 hāme-i perīşānkār-1 fakīr-i hāksārdan rīzān-1 çemen-i beyān ve tarī-sāz-1 hurrem-sebzezār-1 'irfān olduğına şükr-i firāvān idüp efnān-1 ta ' bīrāt-1 pesendīde hiyābān-1 selīka-i hemvār-eserden ser-zede vü saf saf ser-rāh-1 sütūrda (cünbiş-nümāy-1 zuhūr olmağla sāye-fiken-i çemenzār-1 müsvedde olduğ1 cihetden nām-1 Nihālistān ile tesmiye münāsib görüldi. (Çaldak, 2010: 308-309)

\section{Tezkirelere Etkisi}

Hem Türk edebiyatının ilk tezkiresi olan Ali Şir Nevâ'î'nin Mecâlisü'n-Nefầ'is'inde hem de Anadolu sahasında kaleme alınan ilk tezkirelerde şekil ve model olarak Câmî'nin Bahâristân'ının önemli etkisi olmuştur. Ali Şîr Nevâ'̂̂, Câmî’den etkilendiğini şu ifadelerle dile getirir: “ ... ol cümleden biri Hazreti Mahdûmî Şeyhü'l-İslâmî Nûreddîn Abdurrahmân Câmî

\section{Rubâ'î}

Ol kim tokuz felekni akl itse hayâl

Deryâ-yı ulûmıga tapar katre-misâl

Tâ çeşme-i tab'ı dehr ara açtı zülâl

Hayvân suyı birle eyledi mâl-â-mâl

Mundak büzürg-vâr-1 âlî-mikdâr Bahâristân atlıg kitâbıda kim sikiz açıpdur ve sikiz Ravza-i Cennet alar hacâletidin il közidin ihtifâ perdesiga kaçıpdur. Ve anı Sultân-1 sâhib-kırân atı zîveri bile müzeyyel ve elkâbı gevheri bile mü'ekkel kılıpdur. Bir ravzasını bu mevzûn-nevâlık belâbil ve matbû-sadâlıg anadil gül-bângidin reşk-i nigâr-hâne-i Çîn gayret-i Firdevs-i berîn kılupdur." (Ayan vd. 1995: 1-2)

Heşt Bihişt'i kaleme alan Sehi Bey; örnek aldığı eserleri zikrederken Mollâ Câmî’nin Bahâristân'1 ile ilgili şu değerlendirmelerde bulunur: “... hattâ Pârsî dilde Şeyhülislâm zübdetülkirâm ışk kâşânesinün rind-i dürd-âşâmı Hazret-i Mevlânâ Abdurrahmân-ı Câmî kuddise sirruhunun Bahâristân adlu kitâbı ki ana Heşt ravza dirler anun bir ravzası şu'arâ-yı mütekaddimîn zikrinde olup ol tâyife bir vech ile tertîb ve bir resmile tehzîb idüpdür ki bir ravzası hicâbından cennetün sekiz ravzası muhtefî ve İrem Bağı gülzârı bu Bahâristânun Gülistânından hafî olmışdur." (Kut, 1978: 77a) 
Latîfî'nin Bahâristân'ı şiire meraklı ve bu sahada söz sahibi bir arkadaşında gördüğü, Bahâristân'ın yazdığı tezkiresinde etkisi olduğu kendi sözlerinden anlaşılmaktadır: “... ittifâk-1 vifâk ol rûz-1 pîrûzda bu abd-i âsî-i pür-ma'âsî birle elîf ü enîs olmış envâ-1 ma'ârifle ma'rûf e'azz-1 ihvân ve ekrem-i hullânadan bir yâr-i bî-riyâ vardı ki behre-i ilm ü irfầndan bi't-tamâm behremend ve nutk-1 beyân u 'uzûbet-i lisânla beyne'l-enâm emced ü ercümend idi ve tab'-1 pâk ü lutf-1 idrâkle tarîk-ı nazm u inşânun yolına varmış ve fenn-i lugaz u muammâda hayli ad çıkarmış idi. Bir kâmili kâmilü'l-ayâr idi ki safha-i hâtırı vüs'atde sefîne ve cönk gibi ebyât u eş'âr ve letâyif-i esmâr bîhadd ü bî-şümâr idi ve ol kadar tâlib-i fazl u hüner ve râğıb-1 dîvân u defter idi ki bir dem elinden cerâyid ü resâyil ve bir an dilinden kelimât-1 efâzıl gitmezdi.

Beyt:

Vücûdı hılye-i fazl ile mâlî

Hudûd-1 mülk-i nazm u nesre vâlî

Nesr:

Lâbûd ol fâzıll-1 fazilet-me'âb elinde bir kitâb-1 belâğat-nisâb vardı. Açup her fasl u bâbından bu fakîr ü hakîre hayli hitâb itdi. Meger ol kitâb-1 kirâmı cevâb-1 Gülistân Bahâristân-1 Câmî idi efâda'llâhu nûrahû ve kaddese sirrahû kitâb-1 mezkûrı Şeyh-i mezbûr riyâz-1 cinân ve hadâyık-1 rıdvân gibi sekiz ravzaya tevzî' $u$ taksîm idüp bir ravzasında mahsûs u müstakil efầzıl-1 şu'arâ-yı Acem merâtib ü mekâdirin beyân ve menâkıb u me'serlerin 1yân itmiş..." (Canım, 2000: 88).

Âşık Çelebi; Bahâristân ile ilgili şu değerlendirmelerde bulunur: “...şu 'arânun melîkü'l-kelâmı bezm-i belâğatun rind-i dost-kâmi âşâmi yani Monla Câmi şi'r vasfinda Bahâristân'ında ki bahâristân-1 'âlem ana nisbet hâristândur dimişdür ki” (Âș1k Çelebi, 45). "Tabl-girân-1 ma'rifetün dost-kâm-1 âşâmı Monla Câmî Bahâristân'da bunlar yâdına mahsus itdügi bir bâbı ki ol ni'me'lme'âb ve bu ni'me'l-bab sâ'ir kitâblar kusûr bunlar lubâbdur..." (Âş1k Çelebi, 84). ${ }^{14}$

Kınâlı-zâde Hasan Çelebi, Ali Çelebi maddesinde Bahâristân'ın Anadolu'da ve Türk insanı nezdinde ne kadar önemli olduğunu vurgulayan aşağıdaki nükteyi aktarır: "Bir gün ittifâk-1 yârânla seyr ü sohbete âb-misâl revân olmış idük. İttifâk-1 yârândan birinde Bahâristân-1 Mevlânâ Câmî var idi. Hazreti âlî-menkabet ve 'aliyyü'l-menziletün kitâb-1 mezbûr ile'l-ân manzûrları olmagın âyînemisâl mukâbil-i cemâl-i bâ-kemâli olup bir zemân ol behâr-1 'irfâna teferrüc-künân-1 nigerân olduktan sonra ihvândan ba'zı kitâb-1 merkûmun ba'zı hikâyâtını gördünüz mi didükde belî cümlesin temâm idüp hücre-i hâfizada mahzûn ve sanduka-i derûnda mahfuz u meknûn kıldum didükde ihvân u şürekâ 'âdetleri üzre istihzâya başlayup zebân-1 ta'nı her gûş̧eden dirâz itmeğe âğâz itdiler. Merhûm dahı ceste ceste ol kitâbun mukatta'ât u ebyât ve nevâdir ü hikâyâtını ezberden su gibi revân itmekle şürekâ vü akrânı dem-beste vü hayrân oldılar ve her birisi hâmesıfat barmakların kaldurup fazl u 'irfânına imâm getürdiler ben dahı ol zemândan berü ol fầzıl-1 zemânun hilâl-misâl müşârün ileyhi bi'l-menân olacağına âlim ve feth-i ekâlim-i 'irfânla sultân-1 refi'ü'l-unvân olmasina lem ve lemmâ gibi câzim olmışdum ve livâ-yı fazl u 'ulâsı vâsıl-1 fark-1 farkadeyn olacağını re'yü'l- ‘ayn müşâhede kılmış idüm”' (Kınalızâde, 689)

\section{Bahâristân'ın Şiirsel Bir İmge Olarak Kullanımı}

"Divan şiiri geleneğinde bazı kitap adlarının özel isim olmalarının yanında, sözlük anlamlarını da kastedecek şekilde tenasüp, tevriye, cinas gibi edebî sanatlarla bir edebî hususiyet içinde kullanıldıklarını biliyoruz." (Kurnaz, 1989: 44-51) "Bahâristân'ın bu yönüyle şiirlerde zaman

\footnotetext{
${ }^{14}$ Âşık Çelebi, Derviş Çelebi maddesinde, Derviş Çelebi'nin Farsça incelemelerinden söz ederek Bahâristân'dan bir kıt'ayı almıştır (Âşık Çelebi, 256):

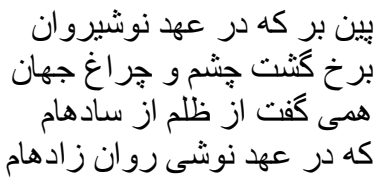




\section{F.Ü. Sosyal Bilimler Dergisi 2016-26/1}

zaman anıldığ1 görülür.” (Macit, 1991: “Bahâristân'1 söz konusu ederken, kelimenin sözlük anlamını hatırlayarak, baharla ilgili diğer unsurlara da yer verirler." (Kurnaz, 1990: 130)

Yukarıdaki bilgiler ve incelenen eserlerde ortaya çıkan bilgiler Bahâristân'ın; klâsik şiirde genellikle teşbih, tevriye telmih, tenasüp, cinas sanatları çerçevesinde; Câmî'ye aidiyeti, zaman-yer çerçevesinde bahar mevsimi, Sa'dî'nin Gülistân ve Bostân'1 ile Attâr'ın Mantıku't-tayr adlı eserleriyle birlikte kullanıldığını göstermektedir.

Mantıku't-tayr u Bahâristân-1 Câmî okuyup

Bülbül-i gülzâr ile bezm ehli oldı hem-nişîn

(Yahya Bey, G / 63 /13-4)

Bahâristân-ı tab'ımda açıldı bir gül-i sûrî

Hacîl eyler anun her bergi evrâk-1 gülistânı

(Hayali, K /46-30)

Yine vassâf-ı berg ü bûy u cûy u bâğ $u$ râğ old 1

Yine meclis Bahâristân-1 Câmî'den nişân old1

$$
\text { (Lebîb, K/ 14-2) }
$$

Bahâristân-1 lutfuna Rahîmî ölmeden girse

Okumaz idi Sa'dîye cenâbunda Gülistânı

(Kütahyalı Rahimi, 320/5)

Bahâristân-1 nazma şöyle virdüm zîb ü zînet kim

Ola bir bülbüli seyr itse $\underline{\text { Sa'dî bu Gülistân1 }}$

(Bursal1 Rahîmî K /1-32)

Mu'allim oldı sabâ mekteb-i gülistânda

Okıtdı goncanun etfâline Bahâristân

(Bursalı Rahîmî K /8-11)

Debistân-1 mahabbetde ruhun şevkiyle dil tıflı

Gülistân okıyup meyli Bahâristânadur şimdi

(Bursalı Rahîmî G 209/3)

Bahâristân-hat münasebeti şiirlerde sık sık başvurulan kullanımlardandır. Sevgilinin yüzü, güzelliği Gülistân olarak hayal edildiğinde ayva tüyleri de Bahâristân olur. Hat, Gülistân, Bahâristân genellikle tevriyeli kullanılır.

Okıdı hüsnün kitâbın hattunı görmek diler

Dil Gülistânı temâm itdi Bahâristân arar

(Âşılk Çelebi, 94/2)

Görenler 'ârızında sandılar hattını cânânun

Kenârında yazılmıșdur Bahâristân Gülistânun

$$
\text { (Âşılk Çelebi, 769) }
$$

Hat ki levh-i 'ârız-1 cânânı yazmışdur tamâm

Safha-i gülde Bahâristânı yazmışdur tamâm

(Emrî, 335/1)

Âl-i evrâk-1 müferrah bir Gülistânun meger

Hurde-bâzîdür kenârinda Bahâristâna hat

(Nehcî, 165/2)

'Anber-i hatıyladur hat-1 Bahâristân-1 hüsn

Gülsitân-1 inbisâ elbette olmaz bî-bisâ

(Sâkıb Mustafa Dede, 95/2) 
Hat-1 cânânedir ma'nâ Bahâristân kitabından

İki mısrâ'-1 mevzûn ebruvânı hüsn bâbından

(Seyyid Mehmet Emin, 2001, 52)

Eline câm al geldi cihânın sa'd-i devrânı

Bahâristân ile zeyn eyledi gülş̧en gülistân

$$
\text { (Hayâlî, 69/1) }
$$

Hatt-1 reyhânuy gülistân-1 ruhunda dil-berâ

Bir bahâristândur etrâfi şebistân-1 hayâl

(Bursalı Rahîmî G 124/3)

Bahâristân'ın bir ders kitabı olarak okunması kelimenin klâsik kullanımları çerçevesinde işlenmiştir:

Cân ile şâkird olup üstâd-1 'şska gül gibi

Gel Bahâristân okuyalum sebakdaș ol bana

(Hayretî, 13/2)

Dersi çıkdı bülbülün şimdi nihâlistâna dek

Geh Gülistân geh Bahâristân'dan okur bir sebak

(Hâzık, 139-2)

Virme dünyâya Behiştî söz bahâristânını

Andelîbe çıka zâgundur gülistânun gözet

(Behiştî, 48/5)

Usûlî, aşağıdaki beyitte, tevriyeli kullandığı kitap isimlerinden hareketle Gülistân'1, Bahâristân ve Bostân'dan daha çok beğendiğini de ima etmiştir:

Gülistân-1 cemâlin kim kitâb-ı hüsn-i behcettir

Komadı revnakın ey dil Bahâristân u Bostânın

(Usûlî, G 72/4)

\section{SONUÇ}

Osmanl1-İran olan edebî ilişkileri siyasi görünümün aksine oldukça canlı ve hareketli olmuştur. İran sahasında Türk şairler yetişirken ve bunlar Farsça eserler kaleme alırken Anadolu sahasında da Türk şairler, Farsça şiirler kaleme almış ya da Fars edebî kültürü etkisinde bir edebî atmosfer oluşturmuşlardır. Türk şairleri üzerinde etkili olmuş Fars şairlerinden biri de Mollâ Câmî'dir. Câmî'nin birçok eseri, özellikle Bahâristân Anadolu sahasında yankı bulmuştur.

Ahlâkî ve edebî bir değer taşıyan Bahâristân'ın Osmanlı sahasında üç, Cumhuriyet döneminde beş tercümesi yapılmıştır. Metnin tamamının tercümesinin yanında eserden seçmeler de yapılmıştır. Bahâristân'ın Dibâce bölümünün veya tamamının şerhleri yapılmış, nicelik olarak az olmakla birlikte lügatları hazırlanmıştır. Osmanlı tezkire geleneği üzerinde önemli etkileri olan esere Nergisî tarafından Nihâlistân adında bir nazire yazılmıştır. Bahâristân'ın edebiyattaki önemli yansımalarından biri de şiirsel bir imge olarak Gülistân ve Bostan la birlikte edebî sanatların sağladığı çağrışım imkânı ve hayal zenginliğiyle kullanılmış olmasıdır.

Türkçe-Farsça edebî ilişkilerinin sanatçı eser mukayeseleri yapılarak, özellikle bu karşılıklı ilişkide etkilenme şeceresinin çıkarılması ilişkilerin boyutunun sağlıklı tespiti açısından önem arz etmektedir. 


\section{KAYNAKÇA}

AKAT, Davut, Şem'i, Şerh-i Bahâristân (giriş-metin), Uludağ Üniversitesi Sosyal Bilimler Enstitüsü, Bursa, 1999. (Yüksek Lisans Tezi)

ARI, Ahmet. (1994) “Sâkıp Mustafa Dede: hayatı, eserleri, edebî kişiliği ve Dîvânı'nın tenkitli metni”, Konya, 1994.

ASLAN, Üzeyir, XVII. Yüzyıl Türk Klâsik Şairlerinden Nehcî Mustafa Dede, Hayatt, Eserleri, Edebî Kişiliği, Tenkitli Metinler, Divan, Tuhfetü's-Sâlikîn ve Hediyyetü'l-Mütereşşidîn, İstanbul, 2005. (Basılmamış Doktora Tezi)

ARSLAN, Mustafa, "Türk Dil Kurumu Kütüphanesi Yz. A. 210 Numarada Kayıtlı Lügat Mecmuası Üzerine Bir Değerlendirme” Turkish Studies-International Periodical For The Languages, Literature and History of Turkish or Turkic Volume 8/1 Winter 2013, 579-600.

AYDEMIR, Yaşar, Behişti Divanı, MEB Yayınları, Ankara, 2000.

CANIM, Rıdvan, Latifî, Tezkiretü'ş-Şu'arâ ve Tabsıratu'n-Nuzamâ (İnceleme-Metin), AKM Yayınları, Ankara, 2000.

ÇAĞMAN, Filiz, "Illustrated Stories from a Turkish Version of Jami’s Baharistan”, Turkish Treasures, 2, 1978, s. 21-27.

ÇALDAK, Süleyman, Nergisî ve Nihâlistân’ı (İncelem-Metin), Kesit Yay. İstanbul, 2010.

ÇAVUŞOĞLU, Mehmet ve Tanyeri, M. Ali, Hayretî, Dîvan, İstanbul, 1981, İstanbul Üniversitesi Edebiyat Fakültesi Yay.

Derviş Muhammed Alî el-Mevlevi, Tercüme-i Bahâristân, Müst. Ömer el-Buhârî, Süleymaniye Nafiz Paşa, 849, 107 vr.

Derviş Muhammed Alî El-Mevlevi, Tuhfe-i âsitân Tercüme-i Bahâristân, Dil Tarih Coğrafya Fakültesi, Mustafa Con. A, 401/XI.

ERDOĞAN, Mustafa, Bursalı Rahmî ve Divanı (http://ekitap.kulturturizm.gov.tr/Eklenti/10600,bursalirahmi-ivanipdf.pdf?0 15. 11.2015)

ERGÜN, Mustafa, DUMAN, Tayyip, "19. Yüzyılda Osmanlı Askerî Okullarının Ders Programları ve Ders Kitapları", Yeni Türkiye, 7,1996. 494-511.

GENÇOSMAN, M. Nuri, Baharistan, MEB Yayınları, Ankara, 1990.

GÜFTA, Hüseyin, Erzurumlu Şair Hâzık Hayatı, Edebî Kişiliği ve Divanı, İstanbul, 2001.

Hızır-zâde Mehmed Fevzi, Bahâristân Tercümesi, Şirket-i Sahâfiye-i Osmâniyye Matbaası, İstanbul, 1227/ 1812-1813, 88 sh.

HUART, CL., "Bahâristân” İslam Ansiklopedisi, MEB Yayınları, C. 2, İstanbul, 1979.

İSEN, Mustafa, Usûlî Dîvanı, Akçağ Yayınları, Ankara, 1990.

KARAİSMAILIOĞLU, Adnan, Bahâristân, Akçağ Yayınları, Ankara, 2002.

KARTAL, Ahmet, “Türk-Fars Edebi İlişkileri”, Şiraz'dan İstanbul'a Türk-Fars Kültür Coğrafyası Üzerine Araştırmalar, Kurtuba Kitap, İstanbul, 2010, s. 13-117.

Kilisli Rıfat Bilge, Bahâristân, Meral Yayınevi, İstanbul, 1970.

Lügat-1 Bahâristân, Türk Dil Kurumu Kütüphanesi, Yz. A 210/16, 237b-261b.

Lügat-1 Bahâristân, DTCF Ktp. İ. Saib II, 1438, 38b-56b.

KILIÇ, Filiz, Âşık Çelebi, Meşa'irü'ş - Şu'arâ - (3 Cilt) (inceleme - metin), İstanbul, 2010.

KILIÇ, Filiz, “Âşık Çelebi”, http://ekitap.kulturturizm.gov.tr/dosya/1213614/h/asikcelebidivanifilizkilic. pdf[erișim tarihi: 15.11 .2105$]$. 44-51.

KURNAZ, Cemal, "Divan Şiirinde Söz Konusu Edilen Kitap Adları Üzerine", Millî Eğitim, 86(1989), 
KUT, Günay, Heşt Bihişt: The Tezkire by Sehi Beg, An Analysis of the First Biographical Work on Ottoman Poets with a Critical Edition Based on MS. Süleymaniye Library, Ayasofya O. 3544. Cambridge, Mass.: Harvard University, 1978.

KUTLUK, İbrahim, Kınalı-zâde Hasan Çelebi, Tezkiretü'ş-şu'arâ, 2 C, Türk Tarih Kurumu Basımevi, Ankara, 1989.

MERMER, Ahmet, Kütahyalı Rahimi ve Divanı, Sahhaflar Kitap Sarayı Yay. İstanbul 2004.

MACIT, Muhsin, “Molla Câmî’nin Osmanlı Edebiyatına Tesiri-I”, Erdem VII, 20 (Ocak 1991), Ankara, (1995), 519-529.

Mehmed Şâkir, Hediyyetü'l-İrfân Der-Şerh-i Bahâristân, İstanbul,

Müntehab-ı Bahâristân, Gazi Hüsrev Kütüphanesi Türkçe Yazmaları, 5103, 1140 (1728), 24 vr.

Müntehab-1 Bahâristân, Gazi Hüsrev Kütüphanesi Türkçe Yazmaları, 2510, 74vr.

Müntehab-1 Bahâristân, Gazi Hüsrev Kütüphanesi Türkçe Yazmaları, 1455, 55 vr.,

Müntehab-1 Bahâristân, Gazi Hüsrev Kütüphanesi Türkçe Yazmaları, 1597.

Müntehab-1 Bahâristân, Gazi Hüsrev Kütüphanesi Türkçe Yazmaları, 1812, 111 vr.

Müntehab-1 Bahâristân, Gazi Hüsrev Kütüphanesi Türkçe Yazmaları, 2768/1, 1-74a.

OĞRAŞ, Rıza, Esad Mehmed Efendi ve Bağçe-i Safâ-Endûz'u, İnceleme Metin, Burdur, 2001.

OKUMUŞ, Ömer, "Bahâristân”, TDVİA, C. 4, İstanbul, 1991, s. 470-471. 1995.

Riyahi, Muhammed Emin, Osmanlı Topraklarında Fars Dili ve Edebiyatı, çev. Mehmet Kanar, İstanbul

SARAÇ, M. A. Yekta, Emrî Divanı, Eren Yay., İstanbul, 2002.

TARLAN, Ali Nihat Hayâlî Bey Dîvânı, Burhaneddin Erenler Matbaası, İstanbul, 1945.

UZUN, Adem, Baharistan’a Göre Sözdizimi, Kırıkkale Üniversitesi Sosyal Bilimler Enstitüsü, Kırıkkale, 1998. (Yüksek Lisans Tezi)

YALSIZUÇANLAR, Sadık, Baharistan, Akçă̆ Yayınları, Ankara, 2001. 
